\title{
Prevalence of hypertension in three rural communities of Ife North Local Government Area of Osun State, South West Nigeria
}

This article was published in the following Dove Press journal:

International Journal of General Medicine

2 December 2013

Number of times this article has been viewed

\author{
Rasaaq A Adebayo' \\ Michael O Balogun' \\ Rufus A Adedoyin ${ }^{2}$ \\ Oluwayemisi A Obashoro- \\ John ${ }^{3}$ \\ Luqman A Bisiriyu ${ }^{4}$ \\ Olugbenga $O$ Abiodun' \\ 'Department of Medicine, \\ ${ }^{2}$ Department of Medical \\ Rehabilitation, Obafemi Awolowo \\ University, ${ }^{3}$ Department of Adult \\ Education, University of Lagos, \\ ${ }^{4}$ Department of Demography and \\ Social Statistics, Obafemi Awolowo \\ University, Ile-Ife, Osun State, Nigeria
}

Correspondence: Rasaaq A Adebayo Department of Medicine, PO Box 196I, Obafemi Awolowo University, Ile-Ife, Osun State, Nigeria

Tel +2348037l496I0

Email radebayo@oauife.edu.ng,

aderasaaq@yahoo.co.uk
Background: The prevalence of hypertension is increasing rapidly in sub-Saharan Africa, but data are limited on hypertension prevalence. In addition, few population-based studies have been conducted recently in Nigeria on the prevalence and correlates of hypertension in both urban and rural communities. Therefore, we determined the prevalence of hypertension in adults in the three rural communities of Ipetumodu, Edunabon, and Moro, in South West Nigeria.

Materials and methods: One thousand adults between 15 and 90 years of age were recruited into this cross-sectional study, over a 6-month period, using a multistage proportional stratified random sampling technique. Sociodemographic data and anthropometric variables were obtained, and resting blood pressure (BP) was measured using an electronic sphygmomanometer Diagnosis of hypertension was based on the JNC VII guidelines, the WHO/ISH 1999 guidelines, and the BP threshold of 160/95 $\mathrm{mmHg}$.

Results: Four hundred and eighty-six men (48.6\%) men and 514 women (51.4\%) participated in the study. Their mean age, weight, height, and body mass index were $32.3 \pm 14.7$ years, $62 \pm 13 \mathrm{~kg}, 1.5 \pm 0.1 \mathrm{~m}$, and $23.02 \mathrm{~kg} / \mathrm{m}^{2}$, respectively. The prevalence of hypertension, based on the 140/90 $\mathrm{mmHg}$ definition, was $26.4 \%$ (Male: $27.3 \%$; Female: $25.4 \%$ ). The prevalence of hypertension, based on the 160/95 mmHg definition, was $11.8 \%$ (Male: $13.5 \%$; Female: $10.1 \%$ ). There were significant positive correlations between BP and some anthropometric indicators of obesity.

Conclusion: The prevalence of hypertension in the three rural communities was $26.4 \%$, indicating a trend towards increasing prevalence of hypertension. There was also a significant positive correlation between anthropometric indicators of obesity and BP in this population.

Keywords: hypertension, Nigeria, prevalence, rural communities

\section{Introduction}

Hypertension is a global public health problem, accounting for substantial morbidity and mortality through heart disease, stroke, blindness, and renal failure. ${ }^{1,2}$ Globally, it accounts for at least $45 \%$ of heart disease, and $51 \%$ of deaths resulting from stroke. ${ }^{1}$ Hypertension was once considered rare in sub-Saharan Africa (SSA), but it has become currently a widespread problem, with immense socioeconomic importance. ${ }^{3}$ In addition, there is evidence that the prevalence of hypertension and cardiovascular diseases is increasing rapidly in SSA. ${ }^{4,5}$ Mass migration of rural Africans to urban areas and rapid changes in lifestyle and risk factors account for this rising prevalence. ${ }^{3}$

The epidemiological picture of hypertension in SSA, compared against other regions, is grimmer, with the region having the highest prevalence, of $46 \%$, compared against $30 \%$ in high-income countries. ${ }^{6,7}$ This high prevalence is expected to be reflected 
in increased prevalence of complications of hypertension in the region. It has also been projected that this prevalence will continue to increase at an alarming rate, with SSA bearing the brunt of the disease burden because of ignorance, poverty, inadequate health care provision, and erosion of traditional lifestyles. ${ }^{3,8,9}$

This will impose considerable strain on scarce health resources, and further impoverish the region. Therefore, the thrust of public health policies within the region should be primary prevention of hypertension. ${ }^{10}$ Success of these primary prevention programs will be dependent on accurate estimates of the prevalence of hypertension in our communities. This will enable precise quantification of the burden imposed by hypertension on our national and regional resources.

Epidemiological transition is at various stages in different places, and the true situation in SSA is largely unknown, ${ }^{11}$ especially in the rural areas. ${ }^{12}$ Therefore, there is an important need for better epidemiological data, and hypertensionrelated outcome trials in SSA. ${ }^{3}$ Data on the prevalence of cardiovascular risk factors, such as hypertension, are scarce in SSA. ${ }^{13}$ In addition, limited information exists about the prevalence of cardiometabolic risk factors and the burden of cardiovascular disease in the adult Nigerian population, especially in the rural setting. ${ }^{14}$ Moreover, few populationbased studies have been conducted recently in Nigeria on the prevalence and correlates of hypertension among the populace, in both urban and rural communities. ${ }^{12,13,15-21}$

Therefore, this study sought to determine the prevalence of hypertension in adult populations living in three rural communities of Ife North Local Government Area (LGA) of Osun State, South West Nigeria. This will further help to define the pattern of hypertension in this rural population, and will also add to national and global databases.

\section{Materials and methods}

One thousand adults of age 15-90 years, from three rural towns of Ife North were recruited into this crosssectional study over a 6-month period, using a multistage proportional stratified random sampling technique. ${ }^{22}$ The minimum sample size was determined using the formula for calculating sample size in the population; ${ }^{23}$ the population of the Ife North LGA was 153,274, according to the 2006 population census. ${ }^{24}$ The participants' data were collected after community mobilization and consent. The permission of traditional rulers of each community was sought, and informed consent was obtained from each participant. The procedure followed the World Health Organization Guidelines for conducting community surveys. ${ }^{25}$
Three major towns, Ipetumodu, Edunabon, and Moro, were randomly selected from the seven major towns of Ife North Local Government. Each of these towns, or communities, is divided further into census enumeration areas (EAs) for demographic purposes; Ipetumodu has 800 EAs, Edunabon has 340 EAs, and Moro has 130 EAs, according to the Ife North Local Government Local Government Office of the National Population Commission. Ten percent of EAs were randomly selected from each town, in proportion to the number of EAs in each town. This translated to 80 EAs for Ipetumodu, 34 EAs for Edunabon, and 13 EAs for Moro. Thereafter, households were randomly selected from each EA, where the selected household had at least one eligible respondent. Six households per EA were randomly selected in Ipetumodu, 10 households per EA in Edunabon, and 23 households per EA in Moro. In each household, at least one eligible and consenting respondent, of age 15 years or older, was interviewed.

Ethical approval was granted by the Ethics and Research Committee of the Obafemi Awolowo University Teaching Hospital, Ile-Ife. All sociodemographic data were obtained using a standard questionnaire, and anthropometric variables and blood pressure (BP) were measured. ${ }^{16,17}$ After about 10 minutes of quiet sitting, three readings of blood pressure (BP) were taken at intervals of 3-5 minutes using an electronic BP monitor (Omron Healthcare Inc, Vernon Hills, IL, USA), after calibration with a mercury sphygmomanometer, according to recommendations of the Nigerian Hypertension Society. ${ }^{26,27}$ The mean of three BP readings was used for analysis, following the manufacturer's guide.

\section{Diagnosis of hypertension}

In 1997, the Federal Ministry of Health and Social Services, Lagos, released the final report of a national survey on noncommunicable diseases in Nigeria, which included the prevalence of hypertension in both the rural and urban areas. ${ }^{27,28}$ In this survey, hypertension was defined as mean systolic blood pressure (SBP) and diastolic blood pressure (DBP) of 160/95 mmHg, using the 1978 definition of the World Health Organization; ${ }^{16,29}$ this was the basis of the cutoff point used in this study. Hypertensive patients on regular drug therapy for hypertension were also included in this study. ${ }^{16}$ Based on the Seventh Report of the Joint National Committee on Prevention, Detection, Evaluation, and Treatment of High Blood Pressure (JNCVII) guidelines ${ }^{30}$ and the World Health Organization and International Society of Hypertension guidelines (WHO/ISH), ${ }^{31}$ a second cutoff point for hypertension, of 140/90 mmHg, was adopted in this study, for comparison with other studies that used this criterion. Using the JNCVII 
classifications of hypertension, ${ }^{16,30}$ participants were categorized as follows for SBP: normal: $<120 \mathrm{mmHg}$; prehypertension: 120-139 mmHg; stage 1 hypertension: 140-159 mmHg; and stage 2 hypertension $\geq 160 \mathrm{mmHg}$. For DBP, participants were categorized as follows: normal: $<80 \mathrm{mmHg}$; prehypertension: $80-89 \mathrm{mmHg}$; stage 1 hypertension: 90-99 $\mathrm{mmHg}$; and stage 2 hypertension $\geq 100 \mathrm{mmHg}$. A subject with both SBP and DBP of $\geq 140 / 90 \mathrm{mmHg}$ is hypertensive by JNCVII ${ }^{30}$ and WHO/ISH 1999 criteria. ${ }^{31}$ With isolated systolic hypertension (ISH), SBP is $\geq 140 \mathrm{mmHg}$, while DBP is $<90 \mathrm{mmHg}$. With isolated diastolic hypertension (IDH), SBP is $<140 \mathrm{mmHg}$, while DBP is $\geq 90 \mathrm{mmHg}$.

Weight was measured, in kilograms using a bathroom weighing scale with the subjects standing, arms hanging naturally at the sides, without footwear. Height was measured, in meters, using a stadiometer, to the crown of the head, the patient standing without any footwear or headgear and looking straight ahead. Waist circumference was measured, using a flexible measuring tape, at the midpoint between the lower border of the rib cage and the iliac crest. ${ }^{32}$

\section{Data analysis}

The data were summarized using descriptive statistics (means, standard deviations, and percentages). Independent $t$-tests were used to compare the age, physical characteristics, and blood pressure of males and females. Significant differences between variables across age groups were determined using analysis of variance (ANOVA) tests. Multiple comparisons between groups were performed using one-way ANOVA with Duncan's post hoc test. $P \leq 0.05$ was considered statistically significant. Data were analyzed using SPSS version 15 statistical software (IBM Corp, Armonk, NY, USA).

\section{Results}

A total of 1,000 adults, with age range 15-90 years, participated in the study: 486 men (48.6\%) and 514 women (51.4\%). Their mean age, weight, height, and body mass index (BMI) were $32.3 \pm 14.7$ years, $62 \pm 13 \mathrm{~kg}, 1.5 \pm 0.1 \mathrm{~m}$, and $23.02 \mathrm{~kg} / \mathrm{m}^{2}$, respectively, as shown in Table 1 . The mean SBP and DBP of all participants were $126 \pm 16.9 \mathrm{mmHg}$ and $77 \pm 12.1 \mathrm{mmHg}$, respectively. The mean SBP was 126.5 $\pm 18.4 \mathrm{mmHg}$ for males, and $125.1 \pm 15.2 \mathrm{mmHg}$ for females $(P>0.05)$. The mean DBP was $77.5 \pm 11.7 \mathrm{mmHg}$ for males, and $76.4 \pm 12.5 \mathrm{mmHg}$ for females $(P>0.05)$. Other descriptive variables except age were significantly different between sexes, as shown in Table $2(P<0.01)$.

Table 3 shows, the distribution of SBP, DBP, and waist circumference (WC), according to age. Differences
Table I Characteristics of the subjects $(n=I, 000)$

\begin{tabular}{lllc}
\hline & Min & Max & Mean \pm SD \\
\hline Age (years) & 15 & 90 & $32 \pm 14.7$ \\
Height $(\mathrm{m})$ & 1.20 & 1.90 & $1.5 \pm 0.1$ \\
Weight $(\mathrm{kg})$ & 30 & 128 & $62 \pm 13.0$ \\
Waist circum $(\mathrm{cm})$ & 32 & 140 & $79.5 \pm 11.7$ \\
Hip circum $(\mathrm{cm})$ & 36 & 152 & $91.2 \pm 12.7$ \\
SBP $(\mathrm{mmHg})$ & 93 & 201 & $126 \pm 16.9$ \\
DBP $(\mathrm{mmHg})$ & 53 & 160 & $77.0 \pm 12.1$ \\
\hline
\end{tabular}

Note: Values expressed as mean \pm standard deviation.

Abbreviations: SD, standard deviation; circum, circumference; SBP, systolic blood pressure; DBP, diastolic blood pressure.

were analyzed using ANOVA, and significant differences between age groups were discovered for WC $(P<0.05)$, SBP $(P<0.05)$, and DBP $(P<0.05)$. Table 3 shows that SBP increased with age up to 61-70 years, while DBP increased up to 41-50 years old.

As shown in Table 4, the estimated prevalence of hypertension, based on the $140 / 90 \mathrm{mmHg}$ definition, was $26.4 \%$ (Male: 27.3\%; Female: 25.4\%). Based on 160/95 $\mathrm{mmHg}$ definition, the estimated prevalence was $11.8 \%$ (Male: 13.5\%; Female: 10.1\%). The prevalence rates of ISH and IDH were $13.1 \%$ and $7.7 \%$, respectively. Out of the 131 participants with ISH, there were 62 males (47.3\%) and 69 females (52.7\%). Out of the 77 subjects with IDH, there were 42 males $(54.5 \%)$ and 35 females (45.5\%).

The relationship between BP and some anthropometric indices is shown in Table 5. There was a significant correlation between WC and SBP and DBP, a significant correlation between hip circumference (HC) and DBP, and a significant correlation between BMI and SBP and DBP.

\section{Discussion}

In this study, the estimated prevalence of hypertension in these three rural communities equals $26.4 \%$, using the $140 / 90 \mathrm{mmHg}$ BP threshold, and equals $11.8 \%$, using the

Table 2 Difference in results between males and females $(n=1,000)$

\begin{tabular}{|c|c|c|c|}
\hline & $\begin{array}{l}\text { Male } \\
(n=486)\end{array}$ & $\begin{array}{l}\text { Female } \\
(n=5 \mid 4)\end{array}$ & $P$-value \\
\hline Age (years) & $32 \pm 13.8$ & $32.6 \pm 15.4$ & 0.495 \\
\hline Height (m) & $1.7 \pm 0.09$ & $1.6 \pm 0.08$ & $0.001 *$ \\
\hline Weight (kg) & $63.5 \pm 13.0$ & $60.9 \pm 11.8$ & $0.000 *$ \\
\hline Waist circum $(\mathrm{cm})$ & $80.5 \pm 1.7$ & $78.5 \pm 11.7$ & $0.006 *$ \\
\hline Hip circum (cm) & $92.4 \pm 11.8$ & $90.1 \pm 13.5$ & $0.005^{*}$ \\
\hline $\mathrm{SBP}(\mathrm{mmHg})$ & $126.5 \pm 18.4$ & $125.1 \pm 15.2$ & 0.182 \\
\hline $\mathrm{DBP}(\mathrm{mmHg})$ & $77.5 \pm 11.7$ & $76.4 \pm 12.5$ & 0.166 \\
\hline
\end{tabular}

Notes: Values expressed as mean \pm standard deviation. *Significant at $P<0.01$. Abbreviations: circum, circumference; SBP, systolic blood pressure; DBP, diastolic blood pressure. 
Table 3 Values of anthropometric variables across age groups $(n=1,000)$

\begin{tabular}{lllll}
\hline $\begin{array}{l}\text { Age group } \\
\text { (years) }\end{array}$ & $\mathbf{n}$ & $\mathbf{W C}$ & SBP & DBP \\
\hline $15-20$ & 223 & $73.98 \pm 7.54^{\mathrm{a}}$ & $122.14 \pm 14.02^{\mathrm{a}}$ & $75.42 \pm 11.20^{\mathrm{a}}$ \\
$21-30$ & 383 & $77.74 \pm\left. 9.2\right|^{\mathrm{a}}$ & $125.01 \pm 15.53^{\mathrm{a}, \mathrm{b}}$ & $76.19 \pm 11.99^{\mathrm{a}}$ \\
$31-40$ & 185 & $82.92 \pm 14.56^{\mathrm{b}}$ & $125.03 \pm 15.03^{\mathrm{a}, \mathrm{b}}$ & $77.25 \pm 11.46^{\mathrm{a}}$ \\
$41-50$ & 89 & $84.35 \pm 12.07^{\mathrm{b}, \mathrm{c}}$ & $129.73 \pm 18.57^{\mathrm{b}}$ & $80.06 \pm 13.54^{\mathrm{a}, \mathrm{b}}$ \\
$51-60$ & 61 & $87.08 \pm 15.30^{\mathrm{b}, \mathrm{c}}$ & $130.85 \pm 24.69^{\mathrm{b}}$ & $76.72 \pm 13.63^{\mathrm{a}}$ \\
$61-70$ & 42 & $88.31 \pm 11.95^{\mathrm{c}}$ & $137.50 \pm 24.92^{\mathrm{c}}$ & $82.33 \pm 13.06^{\mathrm{b}}$ \\
$71+$ & 17 & $77.82 \pm 9.72^{\mathrm{a}}$ & $131.00 \pm 12.43^{\mathrm{b}}$ & $80.00 \pm 11.12^{\mathrm{a}, \mathrm{b}}$ \\
$P$-value & & 0.001 & 0.001 & 0.002 \\
\hline
\end{tabular}

Notes: Values expressed as mean \pm standard deviation. Groups with different superscripts are significantly different, while groups with similar superscripts are not significantly different from each other. For example, WC for age groups I5-20, $2 I-30$, and $7 I+$ (with superscript a) is not significantly different, while WC for age groups $21-30$ and $31-40$ (with superscripts $a, b$ ), is significantly different.

Abbreviations: WC, waist circumference; SBP, systolic blood pressure; DBP, diastolic blood pressure.

160/95 mmHg BP threshold. This implies that, on the basis of the 140/90 $\mathrm{mmHg}$ cutoff point, about three in ten adults were found to be hypertensive, and on the basis of the 160/95 mmHg cutoff, about 1 in 10 adults were found to be hypertensive in these communities. Hypertension prevalence of $11.8 \%$ in this study was higher than the prevalence of $4.5 \%$ among rural dwellers in Ghana (using BP $>160 / 95 \mathrm{mmHg}$ as a cutoff) in 2003, and the estimates of $8 \%-10 \%$ among rural dwellers in Nigeria in $1997.27,28$

The $26.4 \%$ prevalence of hypertension that we obtained in these three rural communities is lower than recent estimates of hypertension prevalence, of $32.9 \%$ and $36.6 \%$, in a semiurban community in Ghana, ${ }^{10}$ and in Nigeria, ${ }^{16}$ respectively, using the 140/90 mmHg definition. This finding corroborates earlier studies, which have observed lower BP and prevalence of hypertension in rural populations, compared against urban and semiurban populations in Africa. ${ }^{3,9,33-36}$ We found that the prevalence of hypertension was higher in men than in women, as also shown in previous studies. ${ }^{33-36} \mathrm{In}$ addition, SBP increased with age up to 61-70 years, while DBP increased up to 41-50 years old. Earlier reports had also indicated increased hypertension with age..$^{28,37,38}$

Table 4 Prevalence estimates by BP definition

\begin{tabular}{llll}
\hline Definition & $\begin{array}{l}\text { General } \\
(\mathbf{n = I , 0 0 0 )}\end{array}$ & $\begin{array}{l}\text { Male } \\
\mathbf{( n = 4 8 6 )}\end{array}$ & $\begin{array}{l}\text { Female } \\
(\mathbf{n}=\mathbf{5} I \mathbf{4})\end{array}$ \\
\hline$\geq 140 / 90 \mathrm{mmHg}$ & 26.4 & 27.3 & 25.4 \\
$\geq 160 / 95 \mathrm{mmHg}$ & $1 \mathrm{I} .8$ & 13.5 & 10.1 \\
$\mathrm{ISH}$ & 3.8 & 47.3 & 52.7 \\
$\mathrm{IDH}$ & 6.4 & 54.5 & 45.5 \\
\hline
\end{tabular}

Note: Values expressed in percentages.

Abbreviations: ISH, isolated systolic hypertension; IDH, isolated diastolic hypertension; BP, blood pressure.
Table 5 Relationship between blood pressure and anthropometric indices

\begin{tabular}{lll}
\hline & SBP & DBP \\
\hline WC & $0.093^{* *}$ & 0.141 \\
HC & 0.027 & $0.083^{* *}$ \\
BMI & $0.075^{*}$ & $0.138^{* *}$ \\
\hline
\end{tabular}

Notes: *Significant at $P<0.05$; **significant at $P<0.01$.

Abbreviations: WC, waist circumference; $\mathrm{HC}$, hip circumference; BMI, body mass index; SBP, systolic blood pressure; DBP, diastolic blood pressure.

The pattern of hypertension in this study showed a prevalence of ISH (13.1\%) higher than that of IDH (7.7\%), similar to earlier reports. ${ }^{37,38}$ Our results also showed that there were significant positive correlations between some anthropometric indicators of obesity (WC, $\mathrm{HC}$, and BMI) and BP. This finding supports earlier investigations, which have reported significant positive correlations between anthropometric factors, such as BMI, and SBP and DBP. ${ }^{16,34,36}$

Some Nigerian authors have recently reported high prevalence of hypertension in some rural communities, as observed in this study. Oladapo et $\mathrm{al}^{14}$ found a $20.8 \%$ prevalence of hypertension, while Onwubere et al, ${ }^{12}$ Asekun-Olarinmoye et al, ${ }^{18}$ Okeahialam et al, ${ }^{11}$ Onwuchekwa et al, ${ }^{19}$ Andy et al, ${ }^{20}$ and Ahaneku GI et $\mathrm{al}^{21}$ reported prevalence of $46.4 \%$, $13.16 \%, 20.9 \%, 18.3 \%, 23.6 \%$, and $44.5 \%$, respectively, in their recent studies. These various studies on hypertension prevalence in Nigeria reported a wide range of prevalence rates using the $\mathrm{BP}$ cutoff point of $140 / 90 \mathrm{mmHg}$.

The prevalence rates range between $13.16 \%-46.4 \%$; the reason for this wide disparity is due partly to methodological differences in these studies. Those who reported higher prevalence rates, such as Onwubere et $\mathrm{al}^{12}(46.4 \%)$ and Ahaneku et $\mathrm{al}^{21}(44.5 \%)$, conducted their studies mainly among elderly and middle-aged adults, in populations of the eastern part of Nigeria. The other studies, from the rest of Nigeria, reported prevalence rates of $13.16 \%-26.4 \%$; in some of these studies, the study populations included adolescents and young adults.

In addition, Asekun-Olarinmoye et al, ${ }^{18}$ Oladapo et al, ${ }^{14}$ and our study report $13.16 \%, 20.8 \%$, and $26.4 \%$ prevalence, respectively, in South West Nigeria. Onwuchekwa et a $1{ }^{19}$ and Andy et $\mathrm{a}^{20}$ found $18.3 \%$ and $23.6 \%$ prevalence, respectively, in the South South Nigeria. Okeahialam et al ${ }^{11}$ reported $20.9 \%$ prevalence in North Central Nigeria. These studies have shown a trend of increasing hypertension in Nigeria; hence, the need to increase efforts aimed at prevention and treatment of hypertension. Screening for hypertension should be intensified, since screening activities are an important component of any prevention and control program. ${ }^{4}$ This is because they 
allow for detection of previously-unaware hypertensive individuals, and providing them with early treatment to prevent cardiovascular disease. ${ }^{4}$ Further studies are necessary to assess the impacts of socioeconomic status and lifestyle in relation to hypertension in this region.

\section{Conclusion}

The prevalence of hypertension in the three rural communities was $26.4 \%$, indicating a trend towards increasing prevalence of hypertension in this rural population. In addition, there were significant positive correlations between anthropometric indicators of obesity and blood pressure in adult residents of these communities.

\section{Acknowledgement}

This project was conducted with assistance from a grant provided jointly by the US Centers for Disease Control and Prevention and the International Union for Health Promotion and Education, France.

\section{Disclosure}

The authors report no conflicts of interest in this work.

\section{References}

1. World Health Organisation. A Global Brief on Hypertension. Silent Killer, Global Health Crisis. Geneva: World Health Organization; 2013.

2. Lim SS, Vos T, Flaxman AD, et al. A comparative risk assessment of burden of disease and injury attributable to 67 risk factors and risk factor clusters in 21 regions, 1990-2010: a systematic analysis for the Global Burden of Disease Study 2010. Lancet. 2012;380(9859):2224-2260.

3. Ogah OS, Rayner BL. Recent advances in hypertension in sub-Saharan Africa. Heart. 2013;99(19):1390-1397.

4. Lemogoum D, Seedat YK, Mabadeje AB, et al: International Forum for Hypertension Control and Prevention in Africa. Recommendations for prevention, diagnosis and management of hypertension and cardiovascular risk factors in sub-Saharan Africa. J Hypertens. 2003;21(11): 1993-2000.

5. Nissinen A, Bothig S, Granroth H, Lopez AD. Hypertension in developing countries. World Health Stat Q. 1988;41(3-4):141-154.

6. Cappuccio FP, Micah FB, Emmett L, et al. Prevalence, detection, management, and control of hypertension in Ashanti, West Africa. Hypertension. 2004;43(5):1017-1022.

7. World Health Organization. Global Status Report on Non-communicable Diseases 2010. Geneva: World Health Organization; 2011.

8. WHO Expert Committee. Hypertension control. World Health Organ Tech Rep Ser. 1996;862:12-83.

9. Pobee JOM. Community-based high blood pressure programs in subSaharan Africa. Ethn Dis. 1993;3 Suppl:S38-S45.

10. Amoah AGB. Hypertension in Ghana: a cross-sectional community prevalence study in Greater Accra. Ethn Dis. 2003;13(3):310-315.

11. Okeahialam BN, Ogbonna C, Otokwula AE, Joseph DE, Chuhwak EK, Isiguzoro IO. Cardiovascular epidemiological transition in a rural habitat of Nigeria: the case of mangu local government area. West Afr J Med. 2012;31(1):14-18.

12. Onwubere BJ, Ejim EC, Okafor CI, et al. Pattern of blood pressure indices among the residents of a rural community in South East Nigeria. Int J Hypertens. 2011;2011:621074.
13. Hendriks ME, Wit FW, Roos MT et al. Hypertension in sub-Saharan Africa: cross-sectional surveys in four rural and urban communities. PLoS One. 2012;7(3):e32638.

14. Oladapo OO, Salako L, Soddiq O, Shoyinka K, Adedapo K, Falase AO. A prevalence of cardiometabolic risk factors among a rural Yoruba south-western Nigerian population: a population-based survey. Cardiovasc J Afr. 2010;21(1):26-31.

15. Ogah OS, Madukwe OO, Chukwuonye II, et al. Prevalence and determinants of hypertension in Abia State Nigeria: results from the Abia State Non-Communicable Diseases and Cardiovascular Risk Factors Survey. Ethn Dis. 2013;23(2):161-167.

16. Adedoyin RA, Mbada CE, Balogun MO, et al. Prevalence and pattern of hypertension in a semiurban community in Nigeria. Eur J Cardiovasc Prev Rehabil. 2008;15(6):683-687.

17. Adedoyin RA, Mbada CE, Bisiriyu LA, Adebayo RA, Balogun MO, Akintomide AO. Relationship of anthropometric indicators with blood pressure levels and the Risk of hypertension in Nigerian adults. Int $J$ Gen Med. 2008;1:33-40.

18. Asekun-Olarinmoye EO, Akinwusi PO, Adebimpe WO, et al. Prevalence of hypertension in the rural adult population of Osun State, southwestern Nigeria. Int J Gen Med. 2013;6:317-322.

19. Onwuchekwa AC, Mezie-Okoye MM, Babatunde S. Prevalence of hypertension in Kegbara-Dere, a rural community in the Niger Delta region, Nigeria. Ethn Dis. 2012;22(3):340-346.

20. Andy JJ, Peters EJ, Ekrikpo UE, Akpan NA, Unadike BC, Ekott JU. Prevalence and correlates of hypertension among the Ibibio/Annangs, Efiks and Obolos: a cross sectional community survey in rural SouthSouth Nigeria. Ethn Dis. 2012;22(3):335-339.

21. Ahaneku GI, Osuji CU, Anisiuba BC, Ikeh VO, Oguejiofor OC, Ahaneku JE. Evaluation of blood pressure and indices of obesity in a typical rural community in eastern Nigeria. Ann Afr Med. 2011;10(2): 120-126.

22. Nworgu BG. Educational Research: Basic Issues and Methodology. Ibadan, Nigeria: Wisdom Publishers; 2006:68-80.

23. Abramson JH, Gahlinger PM. Computer Programs for Epidemiologists (PEPI). Version 3.01. Llanidhoes, UK: Brixton Books; 1999.

24. Population distribution by sex, state, LGA, and senatorial district. Volume III. 2006 Census. Abuja: National Population Commission of Nigeria [Cited June 14, 2013]. Available from: http://www.population.gov.ng.

25. Sethi D, editor. Guidelines for Conducting Community Surveys on Injuries and Violence. Geneva: World Health Organization; 2004.

26. Onwubere B, Kadiri S, editors. Guidelines for the Management of Hypertension in Nigeria. A Recommendation for Healthcare Providers Prepared by the Nigerian Hypertension Society. 1st ed. Enugu, Nigeria: Ezu Books; 2005.

27. Mabadeje AF. WHO-ISH Guidelines for the management of hypertension complications in Africa: The Nigerian experience. Clin Exptl Hypertens. 1999;21:671-681.

28. National Expert Committee on Non-Communicable Diseases (NCD, 1997). Noncommunicable Diseases in Nigeria. Final Report of a National Survey. Lagos, Nigeria: Federal Ministry of Health and Social Services; 1997:1-118.

29. WHO Expert Committee on Arterial Hypertension. Technical Report Series 628. Geneva: World Health Organization; 1978.

30. Chobanian AV, Bakris GL, Black HR, et al. The Seventh Report of the Joint National Committee on Prevention, Detection, Evaluation, and Treatment of High Blood Pressure: the JNC 7 report. JAMA. 2003;289(19):2560-2572.

31. World Health Organization-International Society of Hypertension Guidelines for the Management of Hypertension. Guidelines subcommittee of the World Health Organization. Clin Exp Hypertens. 1999;21(5-6):1009-1060.

32. Crowther NJ, Norris SA. The current waist circumference cut point used for the diagnosis of metabolic syndrome in sub-Saharan African women is not appropriate. PLoS One. 2012;7(11):e48883.

33. Bunker CH, Ukoli FA, Nwankwo MU, et al. Factors associated with hypertension in Nigerian civil servants. Prev Med. 1992;21(6):710-722. 
34. Kadiri S, Walker O, Salako BL, Akinkugbe O. Blood pressure, hypertension and correlates in urbanised workers in Ibadan, Nigeria: a revisit. J Hum Hypertens. 1999;13(1):23-27.

35. Okesina AB, Oparinde DP, Akindoyin KA, Erasmus RT. Prevalence of some risk factors of coronary heart disease in a rural Nigerian population. East Afr Med J. 1999;76(4):212-216.

36. Olatunbosun ST, Kaufman JS, Cooper RS, Bella AF. Hypertension in a black population: prevalence and biosocial determinants of high blood pressure in a group of urban Nigerians. J Hum Hypertens. 2000;14(4): 249-257.
37. Seedat YK, Seedat MA. An inter-racial study of the prevalence of hypertension in an urban South African population. Trans $R$ Soc Trop Med Hyg. 1982;76(1):62-71.

38. Akinkugbe OO, Ojo AO. The systemic blood pressure in a rural Nigerian population. Trop Geogr Med. 1968;20(4):347-356.

\section{Publish your work in this journal}

The International Journal of General Medicine is an international, peer-reviewed open-access journal that focuses on general and internal medicine, pathogenesis, epidemiology, diagnosis, monitoring and treatment protocols. The journal is characterized by the rapid reporting of reviews, original research and clinical studies across all disease areas.
A key focus is the elucidation of disease processes and management protocols resulting in improved outcomes for the patient.The manuscript management system is completely online and includes a very quick and fair peer-review system. Visit http://www.dovepress.com/ testimonials.php to read real quotes from published authors.

Submit your manuscript here: http://www.dovepress.com/international-journal-of-general-medicine-journal 